\title{
Valentina SHAMRAEVA
}

Kharkiv Regional Institute of Public Administration

\section{Foreign Policy of the USA in the context of the Development of Ukrainian-American Collaboration}

\begin{abstract}
The article analyzes the main theoretical approaches to the definition of foreign policy concept of the USA at the modern stage. It considers the main tendencies of the development of the USA and Ukraine's positions on international issues and the ways to solve problems in inter-state collaboration.
\end{abstract}

Key words: foreign policy, international player, national interest, hard power, administration, crisis, indifference, partnership

$\mathbf{T}$ he Ukrainian-American collaboration has become prominent in the process of the development of strategic partnership of Ukraine with other international actors. The development of the inter-state relations between Ukraine and the USA can be arbitrarily divided into several periods which were characterized by the successes of Ukrainian diplomacy as well as by its mistakes and failures. The development of strategic partnership becomes more important taking into account the role of the USA in modern international relations. That is why the issue of the development of Ukrainian-American relations demands more attention and more in-depth studies.

The analysis of the main approaches of American scholars to the acknowledgement of strategic partnership presupposes the defining of its key components, that is 'strategy' and 'partnership'. The initial notion during the analysis is foreign strategy of the state, and strategic partnership is considered as a means of its implementation. This principle is founded on the analysis of the notions of 'strategy' and 'strategic relations' which were systematically studied for the first time in the works of such foreign political scholars as B. G. Liddel Hart (Hart Liddell, 1967), V. Murrey and M. Grimsley (Murray, 1994). Similar approaches may be found in the works of the representatives of Russian political science, namely T. Mozel, S. Proskurina, and P. Tsygankova.

When studying the problems with the development of the modern foreign policy doctrine of the USA at the period of transformation of the world system of the international relations after the end of Cold War it is of great importance to consider the analysis of works of such outstanding American politicians as Z. Brzezinski, S. Huntington, F. Fukuyama and others.

In his research, S. Huntington pays special attention to the civilizational component of international relations' development. That is why, the author believes, in the modern world the rivalry of super states changed into a clash of civilizations. And the main conflicts will take place between the peoples of different cultural identification. 
In the context of the analysis of the development of Ukrainian-American relations the ideas of S. Huntington can lead to a conclusion that the partners belong to different civilizations and this fact makes the development of inter-state interaction difficult but does not exclude the possibilities of mutually beneficial interaction on the basis of respect for independence, sovereignty and national interests of state-partners. This follows from the conclusion of the American researcher that with the aim of preventing an inter-civilizational war it is necessary to realize the uniqueness of civilizations but not the universality, which some USA politicians try to spread in the world, and other civilization leaders should accept poly-civilizational character of the global policy and interact in order to support it (Huntington, 2007).

The supporter of the political school of liberalism, F. Fukuyama, while analyzing the history of the $20^{\text {th }}$ century characterizes it as a period of ideological fight between liberalism, absolutism, and modern Marxism in which Western civilizational values won. Such ideas of the researcher are discussed in his work The End of History (Fukuyama, 1990). Fukuyama's special interest in studying modern foreign policy concept of the USA and the mechanisms of its realization is expressed in his another book, America on the Crossroads (Fukuyama, 2007). In this work, the author examines the main problems of American foreign policy after September 11, and he analyzes the causes of the campaign in Iraq, variants of relations of the USA with the world community, etc. In the context of this research, of special interest is the author's conclusions made on the basis of the formation of foreign policy concept by G. Bush and the achievements and perspectives of American foreign policy of the modern period. The views of leading scientists and analysts, which became the philosophical and politological foundations of foreign policy of the USA in the $21^{\text {st }}$ century, are also analyzed here, in particular as concerns Central and Eastern Europe and the development of the strategic partnership with Ukraine.

The former secretary of the USA, H. Kissinger, presented his views on the history of international relations and their perspectives in his work Diplomacy (Kissinger, 1994). The author sees the world system as the one which is simultaneously characterized by fragmentation and globalization. The author also defends the thesis about the moral victory of liberal democracy ideas at the turn of the $21^{\text {st }}$ century. At the same time, H. Kissinger is not an idealist like W. Wilson or B. Clinton and that is why he does not forecast the creation of one-pole world order with the USA playing the leading role. Nevertheless, he presupposes the role of the USA as "the first among the equal."

Researching the modern problems of working out and finding the sources of the American foreign policy doctrine H. Kissinger underlines the fact that notwithstanding the role of the leader in modern international relations in its foreign policy, the USA often uses the methods of the 'Cold War' times, which are incongruous with the methods of the global society. The other problem he notes is a considerable reduction of American interest in international politics, so he comes to a conclusion about the necessity to give up imperial ambitions and achieve a 'moral consensus' instead of the enforcement of democratic values (Kissinger, 2002).

So, from the ideas of $\mathrm{H}$. Kissinger one may draw the conclusion that Ukraine and the USA belong to different groups of international players, which however does not exclude the possibilities of the development of mutually beneficial collaboration and - under some conditions - also the creation of a strategic partnership. 
Z. Brzezinski is an acknowledged ideologist of American foreign policy and a former advisor of the president of the USA on the issues of national defense. His ideas on the development of international relations after the end of the 'Cold War' are presented most exhaustively in his work The Grand Chessboard (Brzezinski, 1998).

$\mathrm{Z}$. Brzezinski believes that nowadays the role of territorial community is significantly decreasing and the role of other components (economic, technological, military and political ones) of the state potential is increasing.

In his successive works, the author develops the proposed concepts and studies the main principles and perspectives of the development of American foreign policy in modern international relations. In his work The Choice: Global Domination or Global Leadership Z. Brzezinski analyzes the decisions concerning the main political problems which the USA has encountered after the events of September 11. The focus of his attention is the alternatives for American hegemony: domination based on force or leadership based on common values. The author is determined to defend the perspective of leadership combining it with hegemony with the help of which one can control the development of the world international processes (Brzezinski, 2007).

While carrying out research into the practical implementation of the international policy of the USA at the beginning of the 21st century, including the American ideas of the development of Ukrainian-American collaboration, one can name the work of Z. Brzezinski Second Chance (Brzezinski, 2007a), where the author presents a profound analysis of foreign policy activities of three presidents - G. Bush Sr., B. Clinton and G. Bush Jr.

Z. Brzezinski did not avoid the problem of the role of Ukraine in the regional and world international processes, namely the importance of the existence of the Ukrainian state in the context of the European foreign policy interests of the USA. In his work Ukraine in the Geo-Strategic Context he analyzed the actual processes of Ukrainian political life and defended the ideas of the necessity of an independent democratic Ukraine for the creation of the stable zone in Europe (Brzezinski, 2006). This work is like a landmark in the understanding of a process of formation and realization of international policy of the USA in the sphere of the development of Ukrainian-American strategic partnership.

Analyzing the modern condition of the development of modern Ukrainian-American relations one should mention the fact that during the final year of his presidency G. Bush Jr. made a considerable effort to intensify the collaboration with Ukraine. These steps are explained by the acknowledgement of the important role of Ukraine in the development of a regional safety system and US interest in the support for the integration aspirations of Ukraine in the context of American foreign policy interests on the European continent.

It is the United States of America that Ukraine considers to be its main strategic partner on the international arena. The term 'strategic partnership' in American-Ukrainian relations appeared in 2003. In 2008 both countries signed the Route Map - the document which defined the principles of Ukrainian-American inter-state collaboration. The Route Map is founded on the strategic priorities of the development of bilateral relations in a medium-period perspective in political, safety, commercial, economic, energetic and humanitarian spheres as well as in the sphere of scientific-technical and military collaboration.

The signing of the Route Map was aimed to facilitate further deepening of strategic partnership relations between our states (Website www.president.gov.ua). 
On March 31, 2008 at the Ministry of Foreign Affairs of Ukraine one more important document was signed - the Treaty between the Government of Ukraine and the Government of the USA on trade and investment collaboration (Website www.mfa.gov.ua). The Treaty provided for the creation of a permanent bilateral mechanism of collaboration - a Ukrainian-American Council on the Issues of Trade and Investments.

The next step on the way of establishing a strategic partnership level in Ukrainian-American relations were the negotiations on the preparation and signing of The Charter on Strategic Partnership. The document was signed in Washington at the meeting of Foreign Affairs Minister Volodymyr Ogryzko with State Secretary Condoleezza Rice (Website www.uk.wikisource.org).

Essentially, The Charter on Strategic Partnership between Ukraine and the USA is the declaration of the intentions and does not have any official power. Nevertheless, the document is of immense importance as it defines the spheres of collaboration between Kyiv and Washington and proves of the support of the USA for integration aspirations of Ukraine. The Charter on Strategic Partnership opens a wide range of spheres of collaboration in different branches, including economic development and defense.

To achieve the priorities of The Route Map of Ukrainian-American collaboration Ukraine and the USA have set up a joint group on energetic issues. For the economic Ukrainian-American inter-state relations it is of crucial importance to organize the process of regional collaboration. The institution of twin-cities contributes to the intensification of such kind of collaboration.

To emphasize the interests of our state, the activities which are carried out by the Ukrainian minority in the USA are also very important. Taking into account the peculiarities of the political system of the USA such public organizations have a great influence on the process of making foreign policy decisions.

The new chapter in the development of Ukrainian-American relations began with the democratic administration headed by B. Obama coming to the White House. Many analysts associate cardinal changes in the foreign policy concept of the USA in general, as well as its Ukrainian direction in particular, with President Obama. Such approaches stirred some anxiety of Kyiv as for the probability of reducing Ukrainian-American collaboration to the range of tasks of minor importance in the international policy of Washington.

The collaboration of Ukraine and the USA will be close at the time of President Barrack Obama stated the then ambassador of the USA in Ukraine W. Taylor (Website www.newsukraine.com.ua). He substantiated his statement with the fact that the new president had been to Ukraine, knew the country well and also expressed his support for European aspirations of Ukraine. The Ambassador especially underlined the presence in the new President's team of highly qualified specialists on the issues of Ukraine. Besides that, in the team of Obama there are former ambassadors of the USA in Ukraine.

Nevertheless, while analyzing the modern international situation it is necessary to mention the fact that in all the countries without any exception the fight with economic crisis comes to the fore and the American administration was not an exception either. The second in the rank of problems for the United States is the improvement of relationships with European partners as well as Russia. In such context, Ukraine should make considerable efforts to put the real meaning in the proclaimed Ukrainian-American strategic partnership and not to let it remain only the proclamation of the intentions of two parties. 
The original division of roles in the first administration of B. Obama is demonstrative in the international policy of the USA. While B. Obama and State Secretary Hillary Clinton concentrated their attention on the restoration of relations with Russia, the Vice-President of the USA Joseph Biden concentrated his attention on the states which border on Russia explaining to them that 'reloading' will not harm their interests. J. Biden visited Georgia and Ukraine first and he visited Poland and Czech Republic later.

During his official visit to Kyiv he did his best to calm Ukrainian politicians as for the main principles of the construction of the USA foreign policy in Central and Eastern Europe. During his interview to Ukrainian News the Vice-President of the USA said, "We work at our reloading of relations with Russia but I want to reassure you and your people that it won't be at the expense of Ukraine. I'd rather say, I'm sure it would be vice versa, and it will be useful for Ukraine" (Website www.proua.com). D. Biden underlined that the USA considers Ukraine to be a strategic partner in Europe.

The administration of B. Obama thought that the normalization of American-Russian relations would be useful for Ukraine and would not be carried out at the expense of Ukrainian direction of the USA foreign policy. During his stay in Kyiv D. Biden also not once stressed the fact that the USA did not and do not recognize any sphere of interests and believe that every country should choose its way of development by itself.

The main gain of Ukrainian-American relations at the end of 2008 and the beginning of 2009 is giving a legal status to the strategic partnership in inter-state relations. During this period effective measures were taken as for the consecutive support of Euro-Atlantic aspirations of Ukraine by the USA and the work of the Council on the issues of trade and investments started.

The main priorities of Ukraine in the development of Ukrainian-American relations for 2010-2012 were: setting collaboration with B. Obama administration, further deepening of strategic partnership and setting a suitable schedule of mutual visits, realization of the points of the Route Map of Ukrainian-American collaboration and the Ukraine-USA Charter on strategic partnership, and active collaboration within the limits of the interdepartmental coordination group.

Unfortunately, nowadays Ukrainian-American relations are in a period of decreased intensity and some crisis phenomena in political sphere. Namely, in the USA the discussions on the state of the development of democracy in Ukraine were commenced. Thus, in her speeches the State Secretary of the USA, H. Clinton, called for democracy and human rights promotion in those parts of Europe where "the situation is not as it should be" (Website www.news.eizvestia.com). She also emphasized that the elections in Ukraine in 2012 were "a step back from democracy."

Some anxiety of the USA was caused by the steps taken in Ukraine in the economic sphere. Thus, American politicians noted that the wish of Ukraine to review taxes within the limits of the World Trade Organization may considerably complicate bilateral trade relations. The anxiety was expressed to the Minister of Foreign Affairs of Ukraine K. Gryshchenko by Trade Representative of the USA Ron Kirk at the meeting in Washington on October 30, 2012 (Website www.news.mail.ru).

Notwithstanding certain difficulties after the re-election of B. Obama for the second term his administration has maintained the status of Ukraine as a strategic partner state of the United States. 
"It goes without saying, Ukraine remains a state of strategic importance for the United States," noted the USA Ambassador in Ukraine John Tefft (Website www.kontrakty.ua).

Following his words, the aim of the United States' policy towards Ukraine has been unchangeable from the beginning of the relations - "to help Ukrainians to build democratic and economically developed country which is an integral part of the European family of peoples." J. Tefft stressed that this requires democratic commitments from Ukraine, abandonment of selective prosecution and strengthening of integration with European partners. "While retention of corruption, drawbacks in carrying out the latest parliamentary elections and new legislation, namely, the Law on Referendum, potentially alienate Ukraine from democratic standards and norms," noted the American diplomat.

The Ambassador regards the adoption of a new Criminal-Procedure Code to be a step in the right direction, noting that there is still much to be done for its implementation as well as for the restriction of General Prosecutor's Office powers. J. Tefft called the interest of American companies Shevron and Exxon Mobile 'a good start' for the government of Ukraine in energetic sphere. Besides that, he mentioned that the USA highly appreciates participation of Ukraine in peace-making operations, namely in Afghanistan (Website www.kontrakty.ua).

Regarding the whole historiography on the problems of formation and development of Ukrainian-American relations one should underline its variety, the absence of unanimously acknowledged approaches to the sources assessments, mechanisms of realization and the level of the development of Ukrainian-American partnership.

Such kinds of discrepancies in assessments are partially preconditioned by the diversity of the ways and methods used by different leaders of the United States in their plans and actions. Practically all of them, for the benefit for national interests, used inter-state conflicts in Europe, turned to diplomatic demarche which let enforce American influence on European international processes.

Despite the different interpretations of the priorities of the modern American foreign policy by domestic and foreign historiography and political science, in the context of a generalized analysis it can be said that most of them concentrate nowadays on its European vector with less consideration for other regions of the world. At the same time, on the basis of the so-called peripheral systems of international relations, the instruments of the general paradigm of the USA behavior on the international arena have been developed. Having carried out an analysis of the global international policy of the USA, it is easier to understand the reasons for Ukraine belonging to "the zone of indifference" at the beginning of the $20^{\text {th }}$ century and "partnership" in the system of foreign policy priorities of the USA and proclamation of strategic partnership at the beginning of the 21 st century.

\section{Literature}

Biden says that relations between the United States and Russia restart will not be at the expense of Ukraine /proUA/, http://ua.proua.com/news/2009/07/21/154815.html, 21.07.2009.

Brzezinski Z. (2007), Select. World Domination [translation from English], Brzezinski - Moscow Int. relations.

Brzezinski Z. (2006), Ukraine in the geostrategic context [translation from English] Z. BzhezynskyyK. Ed. House "Kiev-Mohyla Academy" 2006, 102 p. (Aktual. svit. dyskusiyi). 
Brzezinski Z. (2007a), Second Chance. Three Presidents and the Crisis of American Superpower, Zbigniew Brzezinski - Moscow Int. relations.

Collins J. M. (1957), Grand strategy. Principles and practice, John M. Collins - M.

Fukuyama F. (1990), The End of History?, "Problems of Philosophy", no. 3.

Fukuyama F. (2007), America at the Crossroads: Democracy, Power, and the Neoconservative Legacy, Moscow.

Hart Liddell B. H. (1967), Strategy, Meridian Book, New York.

Huntington S. (2007), The Clash of Civilizations, Moscow.

Kissinger G. (2002), Is necessary to America foreign policy?

Kissinger H. A. (1994), Diplomacy.

Mozelle T. (2000), Theoretical Foundations of International Relations.

Murray W., Grimsley M. (1994), Introduction on Strategy, New York.

News Of Mfa Of Ukraine, http://www.mfa.gov.ua/mfa/ua/news/detail/11891.htm.

Theoretical basis of Russia's foreign policy, ed. S. А. Proskurina, Изд-во РАГС, М. 2001.

Tsygankov P. (2002), Theory of International Relations.

U.S. accused of undermining Ukraine bilateral relations, http://news.mail.ru/inworld/ukraina/global/ 112/politics/11152172/?frommail=1.

Ukraine - turns democracy, and Russia - calling for the U.S. and Europe - Clinton, http://news.eizvestia.com/news_abroad/full/ukraina-svorachivaet-demokratiyu-a-rossiya-vyzov-dlya-ssha-i-evropy-klinton.

Ukraine and the United States signed a "road map" of bilateral relations, http://www.president.gov.ua/ news/9495.html.

Ukraine retained the status of "strategic country", http://kontrakty.ua/article/55829.

United States-Ukraine Charter on strategic partnership, http://uk.wikisource.org/wiki/\%D0\%A5\% D0\%B0\%D1\%80\%D1\%82\%D1\%96\%D1\%8F_\%D0\%A3\%D0\%BA\%D1\%80\%D0\%B0\%D1\% $97 \% \mathrm{D} 0 \% \mathrm{BD} \% \mathrm{D} 0 \% \mathrm{~B} 0 \_\% \mathrm{E} 2 \% 80 \% 94 \_\% \mathrm{D} 0 \% \mathrm{~A} 1 \% \mathrm{D} 0 \% \mathrm{~A} 8 \% \mathrm{D} 0 \% 90$.

Washington Charter confirms the guarantee Ukraine's security, http://www.newsukraine.com.ua/ news $/ 133461 /$.

\section{Streszczenie}

\section{Polityka zagraniczna USA w kontekście rozwoju współpracy ukraińsko-amerykańskiej}

Artykuł analizuje główne teoretyczne podejścia do definiowania konceptu polityki zagranicznej USA we współczesnym świecie. W tekście poruszono zagadnienia głównych tendencji w rozwoju stanowisk USA i Ukrainy w sprawach międzynarodowych i sposobów rozwiązywania problemów we współpracy obu państw.

Słowa kluczowe: polityka zagraniczna, gracz międzynarodowy, interes narodowy, twarda władza, partnerstwo 
